\title{
Postoperative Objective Tinnitus
}

Marie-Louise Kulas Søborg, MD, Nina Imbæk, MD, Mette Lindelof, MD, and William Kristian Karlsson, MD

Neurology ${ }^{\circledR}$ 2021;96:230. doi:10.1212/WNL.0000000000011126

A 54-year-old man with recurrent frontal malignant glioma with invasive growth into the frontal sinus, skull base, nasal cavity, and right orbit developed concurrent rhinoliquorrhea, pneumocephalus, and objective tinnitus after tumor resection. The tinnitus was audible for both the patient and people in his vicinity (video 1 ). The sound was not pulse-synchronous and accentuated upon upright positioning. Tinnitus and rhinoliquorrhea remitted simultaneously after approximately 3 months, implying a causative iatrogenic dural leak. This phenomenon has not been described previously, with objective tinnitus typically being caused by vascular malformations, venous hum from the internal jugular vein, or myoclonus. ${ }^{1,2}$

\section{Study Funding}

No targeted funding reported.

\section{Disclosure}

The authors report no disclosures relevant to the manuscript. Go to Neurology.org/ $\mathrm{N}$ for full disclosures.

Appendix Authors

\begin{tabular}{lll}
\hline Name & Location & Contribution \\
\hline $\begin{array}{l}\text { Marie-Louise Kulas } \\
\text { Søborg, MD }\end{array}$ & $\begin{array}{l}\text { University Hospital of Zealand, } \\
\text { Roskilde, Denmark }\end{array}$ & Drafted the manuscript for intellectual content \\
\hline Nina Imbæk, MD & $\begin{array}{l}\text { Bispebjerg Hospital, } \\
\text { Copenhagen, Denmark }\end{array}$ & Revised the manuscript for intellectual content \\
\hline Mette Lindelof, MD & $\begin{array}{l}\text { University Hospital of Zealand, } \\
\text { Roskilde, Denmark }\end{array}$ & $\begin{array}{l}\text { Acquisition of data and video footage, revised the } \\
\text { manuscript for intellectual content }\end{array}$ \\
\hline $\begin{array}{l}\text { William Kristian } \\
\text { Karlsson, MD }\end{array}$ & $\begin{array}{l}\text { University Hospital of Zealand, } \\
\text { Roskilde, Denmark }\end{array}$ & $\begin{array}{l}\text { Acquisition of data, revised the manuscript for } \\
\text { intellectual content }\end{array}$ \\
\hline
\end{tabular}

\section{References}

1. Ward PH, Babin R, Calcaterra TC, Konrad HR. Operative treatment of surgical lesions with objective tinnitus. Ann Otol 1975;84: $473-482$.

2. Alicandri-Ciufelli M, Soloperto D, Palma S, Marrara A, Genovese E. A clockwork ear. Neuropediatrics 2012;43:146-148.

\section{Correspondence}

Dr. Kulas Søborg

maro-kulas@hotmail.com

\section{MORE ONLINE}

- Video 


\section{Neurology}

Postoperative Objective Tinnitus

Marie-Louise Kulas Søborg, Nina Imbæk, Mette Lindelof, et al.

Neurology 2021;96;230 Published Online before print October 27, 2020

DOI 10.1212/WNL.0000000000011126

This information is current as of October 27, 2020

\section{Updated Information \&} Services

References

Subspecialty Collections

Permissions \& Licensing

Reprints including high resolution figures, can be found at: http://n.neurology.org/content/96/5/230.full

This article cites 2 articles, 0 of which you can access for free at: http://n.neurology.org/content/96/5/230.full\#ref-list-1

This article, along with others on similar topics, appears in the following collection(s):

Clinical neurology examination

http://n.neurology.org/cgi/collection/clinical_neurology_examination Tinnitus

http://n.neurology.org/cgi/collection/tinnitus

Information about reproducing this article in parts (figures,tables) or in its entirety can be found online at:

http://www.neurology.org/about/about_the_journal\#permissions

Information about ordering reprints can be found online:

http://n.neurology.org/subscribers/advertise

Neurology ${ }^{\circledR}$ is the official journal of the American Academy of Neurology. Published continuously since 1951, it is now a weekly with 48 issues per year. Copyright @ 2020 American Academy of Neurology. All rights reserved. Print ISSN: 0028-3878. Online ISSN: 1526-632X.

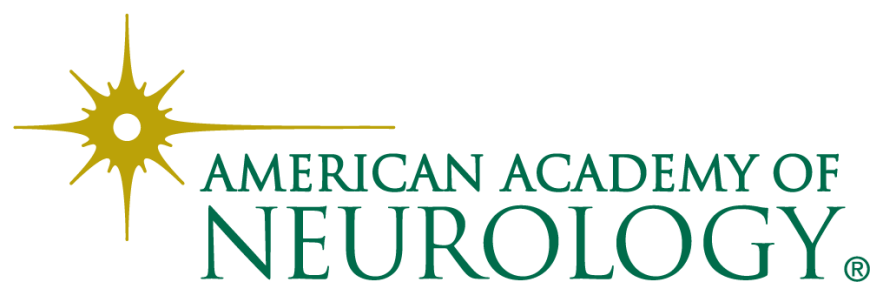

